Acta vet. scand. $1973,14,292-300$.

From the Department of Anatomy and Histology and the Laboratory of Electron Microscopy, and the Department of Pathology,

Royal Veterinary College, Stockholm, Sweden.

\title{
FINE STRUCTURE \\ OF THE REINDEER CORNEA \\ IN NORMAL CONDITIONS AND IN \\ KERATITIS
}

By

G. Winqvist and C. Rehbinder

WINQVIST, G. and C. REHBINDER: Fine structure of the reindeer cornea in normal conditions and in keratitis. Acta vet. scand. $1973,14,292-300$. - The fine structure of the reindeer cornea in normal conditions and in spontaneous keratitis was described. There were more layers of squamous and fewer layers of polyhedral cells than in pigs, cattle and horses.

Mild cases of corneal opacity just had some swollen superficial epithelial cells.

When fully developed the keratitis had all the characteristics of an acute inflammation. Swelling or shrinking of the epithelial cells with or without degenerative nuclear changes were common. A striking alteration of the epithelial cells was the irregular appearance of the filaments which was frequently observed. In some cases there was pronounced intercellular oedema with desquamation of the superficial squamous cells and occasional neutrophils in the intercellular space. The stroma was the site of oedema, infiltration of leukocytes and vascularization.

The aetiology and pathogenesis of the disease are not yet established but experimental research on these problems is in progress.

cornea structure; reindeer; keratitis.

Keratitis in reindeer, mainly in calves, appears with rather high frequency in some reindeer herding areas in the northern parts of Scandinavia, USSR and North America (Bergman 1912, Hadwen \& Palmer 1922, Nordkvist 1960, Rehbinder 1970). The 
frequency is highest in summer but sometimes outbreaks may occur in late spring.

The initial clinical stage of the disease often begins with a central greyish swelling of the cornea, rather often combined with an ulcer. It usually leads to the cornea becoming entirely greyish and thicker during the progress of the disease (Rehbinder).

In a rather early phase of the disease the animal is totally blind on the affected eye. Keratitis may appear in one or both eyes, the former case being slightly predominant. The morbidity rate is definitely higher in more densely gathered herds in which about $30 \%$ or more of the fawns may be affected only a couple of weeks after the appearance of the first cases. In small and scattered herds the morbidity rate is seldom above $1 \%$ (Rehbinder).

The purpose of the present investigation is to describe the changes in the fine structure of affected corneae. It was considered suitable to describe the ultrastructure of the normal reindeer cornea as well, since this has not previously been done.

\section{MATERIAL AND METHODS}

Naturally affected reindeer-calves showing clinical symptoms of keratitis, were selected out of herds in Lappland, gathered for marking of the calves by the owners.

The selected animals were examined with a lamp and the macroscopical picture of each eye was described. Five of the animals were then killed and the corneae were immediately taken out for fixation. Six corneae from four clinically normal reindeer-calves served as controls. All corneae were fixed immediately at varying temperatures in three per cent glutaraldehyde solution buffered to $\mathrm{pH} 7.4$ with cacodylate. They were kept in the glutaraldehyde solution for varying times. Before embedding small pieces were postfixed in $2.67 \%$ osmium tetroxide solution buffered with s-collidine. After embedding in Epon 1- $\mu$-thick sections were cut and stained with toluidine blue for light microscopy and thin sections were prepared on an LKB ultrotome, picked up on uncoated copper grids, stained with uranyl acetate and examined in a Siemens Elmiskop I at $60 \mathrm{kv}$ and magnifications varying between about 600 and 12000 times. 


\section{RESULTS}

Normal reindeer cornea ( 4 cases, 6 eyes)

The endothelium was 3.5 to $5 \mu$ thick and had many mitochondria and some narrow cisternae of rough surfaced endoplasmic reticulum. A few microvilli were protruding into the anterior chamber of the eye.

The lamina lamitans posterior (Descemet's membrane) was 6 to $11 \mu$ thick and had a very smooth and straight border on the endothelial side and a very homogeneous opaque appearance in its basal half. The anterior half, on the other hand, had a periodic and lattice-like ultrastructure resembling that described for man (Pouliquen 1969). The border to the substantia propria was uneven and a few strands and lamellae of the lamina appeared among the collagen fibrils just above the border.

The substantia propria was 400 to $500 \mu$ thick and had the same ultrastructure as described for man and some other species (Jakus 1954, 1964, Pouliquen 1969, Shively \& Epling 1970), with numerous sheets of parellel collagen fibrils, the direction of fibrils in one sheet forming approximately right angles with those in the next. Between the sheets occasional very flattened keratocytes were observed. They had only few mitochondria but a fair amount of rough surfaced endoplasmic reticulum.

The lamina limitans anterior (Bowman's membrane) was 2 to $3 \mu$ thick and had a less regular structure, the collagen fibrils forming a loose and almost reticular pattern. It ended at the distinct basement membrane of the epithelium.

Like some other large animals the reindeer has a thick corneal epithelium (cf. Tretjakoff 1912, Prince et al. 1960, Ehlers 1970). It measured 80 to $100 \mu$ and had 15 to 20 layers of cells. The basal cells were irregularly columnar with numerous hemidesmosomes. The cell membranes of adjacent cells lay very close together and had many interdigitations. Desmosomes were small and few in the basal half of these cells but increased in size and number in the anterior half. The cytoplasm contained a number of mitochondria and a few cisternae of rough surfaced endoplasmic reticulum. The main component, however, was a multitude of fine filaments which rendered the cytoplasm very opaque. They were mainly oriented along the long axis of the cell.

The next two to five layers had polyhedral cells with irregularly rounded or oval nuclei. As in the previous layer the inter- 
cellular space was very narrow and the cell membranes had a large number of interdigitations and numerous small but distinct desmosomes. The mitochondria and the endoplasmic reticulum appeared to be gradually reduced in each subsequent layer and the cytoplasm was packed with fine, randomly orientated filaments. The basal and polyhedral cells took up more than half of the height of the epithelium.

The remaining 10 to 14 layers consisted of increasingly flattened squamous cells with flat nuclei. In the anterior layers only occasional nuclei were encountered in each section. Even here mitochondria were present although small and few. The cytoplasm was full of filaments the orientation of which tended to parallel the cell surface.

Up to the most anterior two or three layers the intercellular spaces were very narrow. The cell membranes were winding and had numerous desmosomes. The most anterior layers had very flat cells with a somewhat vacuolated cytoplasm and less distinct filaments. The intercellular spaces were a little widened in this area and the desmosomes were not as distinct as in the posterior layers. Many connections between cells had separated in the desmosomes leaving a number of microvilli projecting into the intercellular space. The surface cells also had small microvillus-like protrusions on their free surface.

\section{Structure of affected corneae}

Focal opacity (1 case, both eyes)

The endothelium, the substantia propria and adjacent laminae were unchanged. The epithelium was partly thickened (up to $170 \mu$ ). Some of the superficial squamous cells appeared swollen and pale but no widening of the intercellular spaces was observed. There were numerous light areas in the cytoplasm, indicating an intracellular oedema. The polyhedral and basal cells had a normal appearance.

General strong opacity. Blindness (2 cases, 3 eyes)

These corneae showed intense and acute inflammatory changes. The endothelium was fragmentary in sections of paraffinembedded material and totally missing in all blocks embedded in Epon. The posterior limiting lamina appeared unchanged. Particularly in its anterior half the substantia propria was very 
oedematous with swolien keratocytes and infiltrated with leukocytes, mainly neutrophilic granulocytes. In some areas the orderly structure of the stroma was completely lost, only a few bundles of collagen fibrils remaining in a slightly flocculent ground substance with many neutrophils and monocytes. Macrophages with irregular granular masses of low electron density in their cytoplasm were also present. The anterior limiting lamina was affected in a similar way, but to a lesser degree.

The epithelium also showed striking changes. A prominent feature in two of the three corneae in this group was a heavy oedema in and between the cells. In some areas the basal cells were separated by broad clefts, filled with a fluid of low electron density. In the next layers the broad intercellular spaces were bridged by long processes connected by desmosomes. Some of these were broken either in or near the desmosomes. The superficial cells had narrower intercellular spaces but in some areas their number was greatly reduced and the corneal surface was covered with an exudate of the same appearance as the intercellular fluid. Occasional leukocytes were present in the intercellular space.

An intracellular oedema was observed in many cells as clefts with a slightly floccuient material. Other cells were just very pale and swollen. In the basal cell layer some cells were pale and swollen and others dark and shrunken.

Another characteristic feature was a change in the filaments normally being spread evenly throughout the cytoplasm. Here, they were grouped in thick tufts leaving parts of the cytoplasm free of filaments. In these areas the cytoplasm contained rough surfaced endoplasmic reticulum and many polyribosomes.

Many nuclei appeared normal but others were pycnotic or showed other degenerative changes.

General strong opacity and central ulcer.

Blindness ( 2 cases, 3 eyes)

In these cases the cornea showed the same changes as in the previous group. In the vicinity of the ulcer the inter- and intracellular oedema of the epithelium was very marked and the filaments were gathered into thick bundles some of which ended at the desmosomes. Dense bodies and vacuoles were common in the cytoplasm and degenerative nuclear changes were not in- 
frequent. Neutrophils were present in or between some epithelial cells.

At the site of the ulcer there was a strong reduction in the number of epithelial cells down to the anterior limiting lamina. In the periphery of the ulcer basal cells of rather flattened shape were lying along the basement membrane.

\section{DISCUSSION}

The normal reindeer cornea differs from that of the pig, cattle and horse (Prince et al. 1960) in respect of the proportions of polyhedral and squamous cells of the epithelium. A similar arrangement with few layers of polyhedral cells and many layers of squamous cells has been observed in the corneal epithelium of whales and seals (Ehlers 1970) but also in the Swedish elk (unpublished observation by the authors). It seems likely that as many as 10 to 15 layers of squamous cells would offer a good mechanical protection. Apart from the difference in thickness or proportions of the epithelial layers the reindeer cornea is similar in ultrastructure to that of many other species (Jakus 1954, 1964, Sheldon 1956, McTigue 1967, Pouliquen 1969, Shively \& Epling 1970).

In slightly affected corneae the only change observed was some oedema in the superficial epithelial cells. Similar changes can be produced experimentally by u.v. radiation (Buschke et al. 1945, Pitts et al. 1969) and by bacterial infection (Wessel \& Rácz 1967). It seems likely that these cells were the first to be attacked by the aetiological agent.

The oedema and leukocyte infiltration of the epithelium as well as of the stroma is reminiscent of the changes described in experimental Shigella-keratitis (Wessel d Rácz), and Listeriakeratitis in the guinea pig (Rácz et al. 1970, Tenner et al. 1970). Even in these types of keratitis the first changes occurred in the superficial epithelium. The picture also resembles that of healing corneal wounds (Latessa \& Ross 1964).

The picture differs, on the other hand, in many respects from that of herpes keratitis (Dawson et al. 1968) where virus particles and necrosis of the stroma were prominent features, from that of vaccinia keratitis (Malas et al. 1971) where the basal epithelial cells were primarily affected leading to necrosis of the polyhedral cells and eventually ulcers by interruption of the 
surface epithelium covering the necrotic area, and from that of the eye changes in malignant catarrhal fever (Jubb et al. 1960) which were characterized by an exudative keratitis, iridocyclitis and retinitis with lymphocytic perivascular cuffs.

The present observations also differ considerably from allergic reactions of the cornea (Shirasawa 1966) which are characterized by antigen-antibody precipitates in the stroma near the limbus and infiltrations of monocytes, lymphocytes and plasma cells.

In the present study virus was not observed morphologically. Neither have routine virological methods (Rockborn \& Rehbinder, unpublished observations) given any indication of a viral aetiology.

In conclusion the observations reported here would indicate that the reindeer keratitis does not have specific features giving a clue to its aetiology.

\section{ACKNOWLEDGEMENT}

The skilful technical assistance by Mrs. Birgitta Ivarsson is gratefully acknowledged.

\section{REFERENCES}

Bergman, A.: Smittosam hornhinneinflammation, keratitis infectiosa hos ren. (Contagious keratitis in reindeer). Skand. Vet.-T. 1912, $2,145,177$.

Buschke, W., J. S. Friedenwald \& S. G. Moses: Effects of ultraviolet irradiation on corneal epithelium: Mitosis, nuclear fragmentation, posttraumatic cell movements, loss of tissue cohesion. J. cell. comp. Physiol. 1945, 26, 147-164.

Dawson, C. R., B. Togni \& T. E. Moore, Jr.: Structural changes in chronic herpetic keratitis studied by light and electron microscopy. Arch. Ophthal. 1968, 79, 740-747.

Ehlers, N.: Morphology and histochemistry of the corneal epithelium of mammals. Acta anat. (Basel) 1970, 75, 161-198.

Hadwen, S. \& L. J. Palmer: Reindeer in Alaska. U. S. Department of Agriculture, Bulletin no. 1089, Washington 1922.

Jakus, M. A.: Studies on the cornea I. The fine structure of the rat cornea. Amer. J. Ophthal. 1954, 38, 40-52.

Jakus, M. A.: Ocular fine structure. Little, Brown \& Co., Boston, Mass. 1964.

Jubb, K. V., L. Z. Saunders \& P. J. Stenius: Die histologischen Augenveränderungen beim bösartigen Katarrhalfieber des Rindes. (The histological eye changes in malignant catarrhal fever in cattle). Schweiz. Arch. Tierheilk. 1960, 102, 392-400. 
Latessa, A. J. \& M. H. Ross: Electron microscope studies of nonpenetrating corneal wounds in the early stages of healing. Exp. Eye Res. 1964, 3, 298-303.

Matas, B., W. Spencer, T. Hayes \& C. R. Dawson: Morphology of experimental vaccinial superficial punctate keratitis - a scanning and transmission electron microscopy study. Invest. Ophthal. $1971,10,348-356$.

McTigue, J. W.: The human cornea. A light and electron microscopy study of the normal cornea and its alterations in various dystrophies. Trans. Amer. ophthal. Soc. 1967, 65, 591-660.

Nordkvist, M.: Renens sjukdomar. Kort översikt. (Diseases of the reindeer. Short survey). Lappväsendet - Renforskningen, Småskrift 4, 1960 .

Pitts, D. G., J. E. Prince, W. J. Butcher, K. R. Kag, R. W. Bowman, H. W. Casey, D. G. Richey, L. H. Mori, J. E. Strong \& T. J. Tredici: The effects of ultraviolet radiation on the eye. USAF School of Aerospace Medicine. Aerospace medical division (AFSC) Brooks Air Force Base, Texas 1969.

Pouliquen, Y.: Atlas d'Histologie et d'Ultrastructure du Globe Oculaire. (Atlas of the Histology and Ultrastructure of the Eye). Masson \& Cie, Paris 1969.

Prince, J. H., C. D. Diesem, I. Eglitis \& G. L. Ruskell: Anatomy and histology of the eye and orbit in domestic animals. Charles C. Thomas, Publisher, Springfield, Ill., USA 1960.

Rácz, P., K. Tenner \& K. Szivessy: Electron microscopic studies in experimental keratoconjunctivitis listeriosa. Acta microbiol. Acad. Sci. hung. 1970, 17, 221-236.

Rehbinder, C.: Observations of 1st instar larvae of nostril fly (Cephenomyia Trompe L.) in the eye of reindeer and their relation to keratitis in this animal. Acta vet. scand. 1970, 11, 338-339.

Sheldon, H.: An electron microscopic study of the epithelium in the normal mature and immature mouse cornea. J. biophys. biochem. Cytol. 1956, 2, 253-261.

Shirasawa, H.: Die elektronenoptisch darstellbare Morphe der allergisch-hyperergischen Reaktionen an der Cornea des Kaninchens und Meerschweinchens. (The electron optically demonstrable allergic-hyperergic reactions in the cornea of rabbits and guinea-pigs). Frankfurt. Z. Path. 1966/67, 76, 270-305.

Shively, J. N. \& G. P. Epling: Fine structure of the canine eye: Cornea. Amer. J. vet. Res. 1970, 31, 713-722.

Tenner, K., P. Rácz \& B. Sheren: Comparative electron-microscopic study of dysenteric and listerellous keratoconjunctivitis. Arkh. Pat. 1970, 32, 12-16.

Tretjakoff, D.: Das Auge vom Renntier. (The eye of the reindeer). Int. Mschr. Anat. Physiol. 1912, 29, 150-202.

Wessel, W. \& P. Rácz: Elektronenmikroskopische Untersuchungen der Cornea bei experimenteller Shigellen-keratitis. (Electron microscopical investigations of the cornea in experimental Shigellakeratitis). Virchows Arch. Path. Anat. 1967, 342, 109-128. 


\section{SAMMANFATTNING \\ Ultrastrukturen $i$ renens hornhinna under normala förhallanden och vid keratit.}

Ultrastrukturen hos renens normala cornea och förändringarna i samband med keratit har beskrivits. Det förelåg normalt hos renen fler lager plattepitel och färre lager polyedriska celler än hos svin, nöt och häst.

I milda fall av corneal grumling iakttogs enbart några ansvällda ytliga epitelceller. Vid fullt utvecklad keratit förelåg alla karakteristika för en akut inflammation. Ansvällning eller skrumpning av epitelcellerna med eller utan degenerativa kärnförändringar förekom ofta. En påtaglig och vanlig förändring $i$ epitelcellerna var tonofilamentens oregelbundna fördelning med ansamling i tjoka buntar. I en del fall sågs ett kraftigt intra- och intercellulärt ödem med deskvamation av de ytliga plattepitelcellerna och med enstaka neutrofiler i intercellularrummen. Stromat var säte för ödem, leukocytinfiltration och vaskularisering. Sjukdomens etiologi och patogenes är ännu ej klarlagda, men undersökningar gällande dessa problem pågår.

(Received April 27, 1972).

Reprints may be requested from: Claes Rehbinder, Department of Pathology, Royal Veterinary College, S-104 05 Stockholm 50, Sweden. 
G. Winquist and C. Rehbinder:

Fine Structure of the Reindeer Cornea in Normal Conditions and in Keratitis.

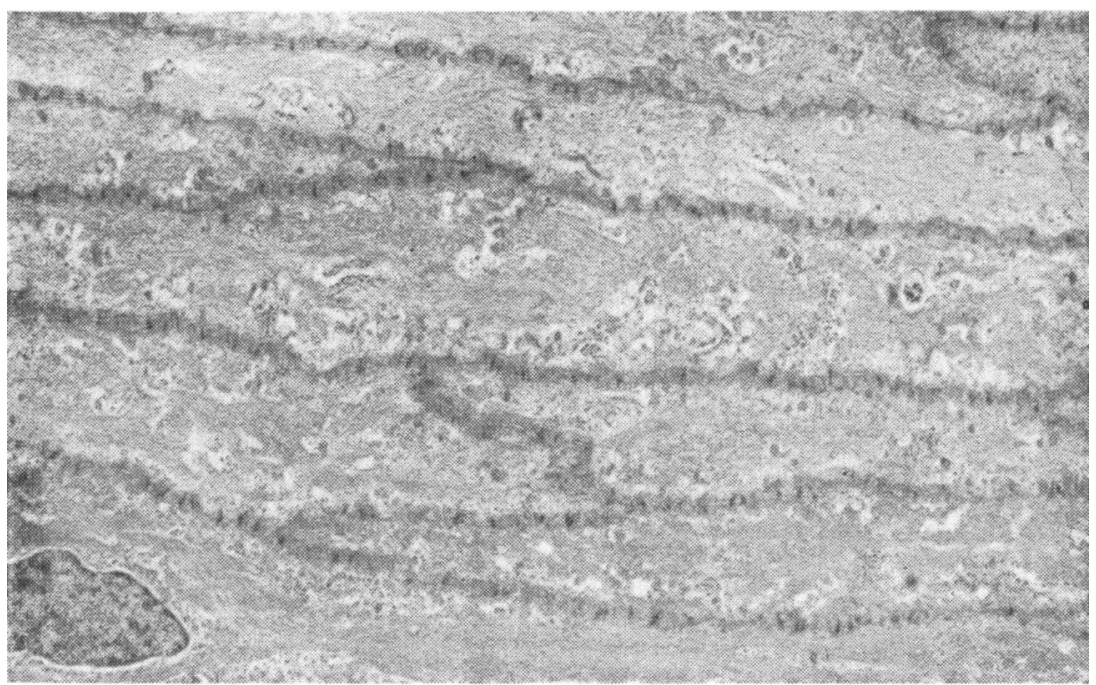

F i g u r e 1. Normal squamous epithelial cells. $5,000 \times$.

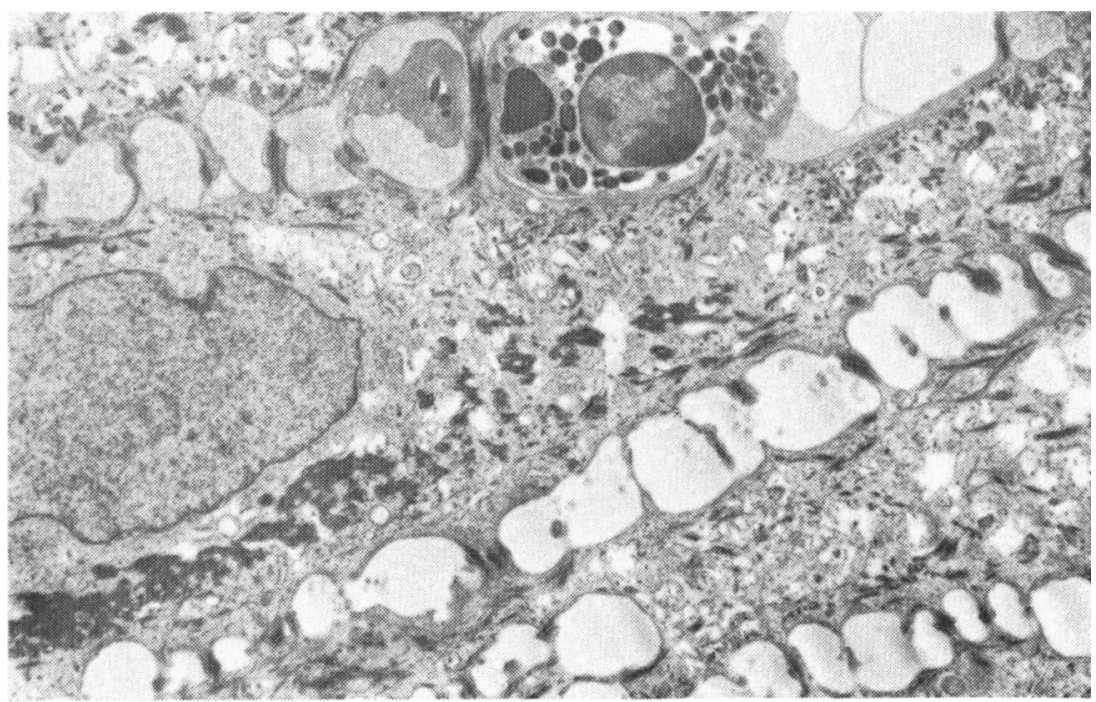

F i g u re 2. Squamous epithelial cells in keratitis. Note intra- and intercellular oedema, neutrophil in intercellular space, and dense tufts of filaments. $5,000 \times$. 


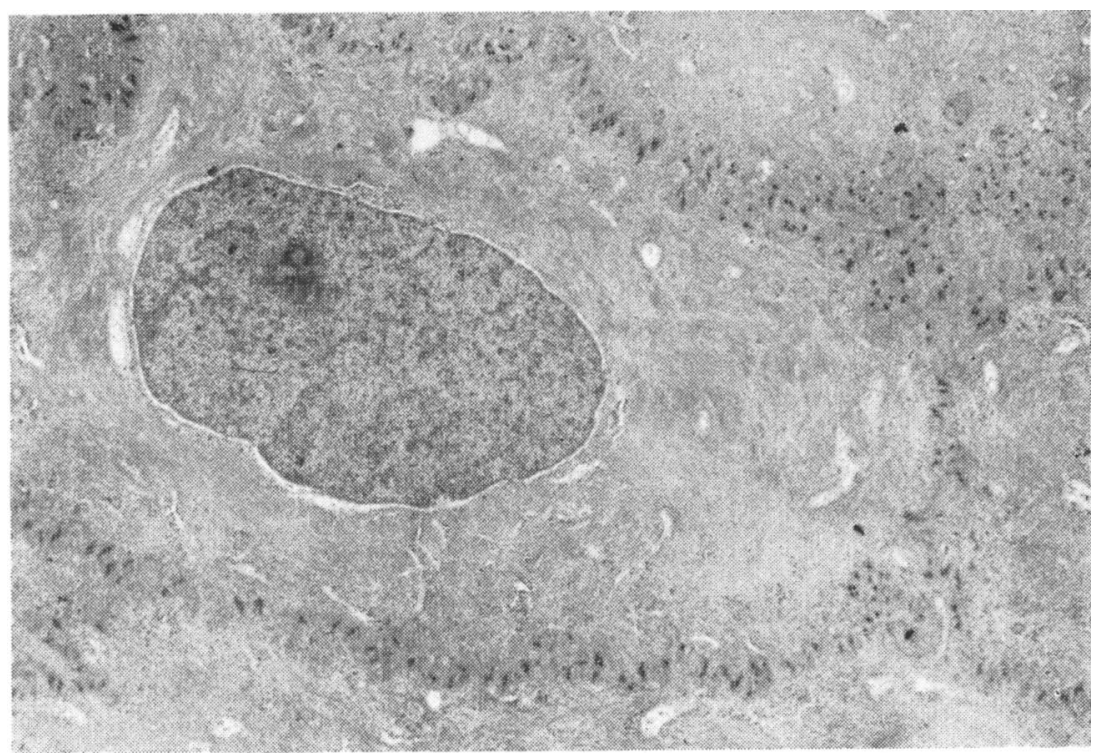

F i g u r e 3. Normal polyhedral cells. $5,000 \times$.

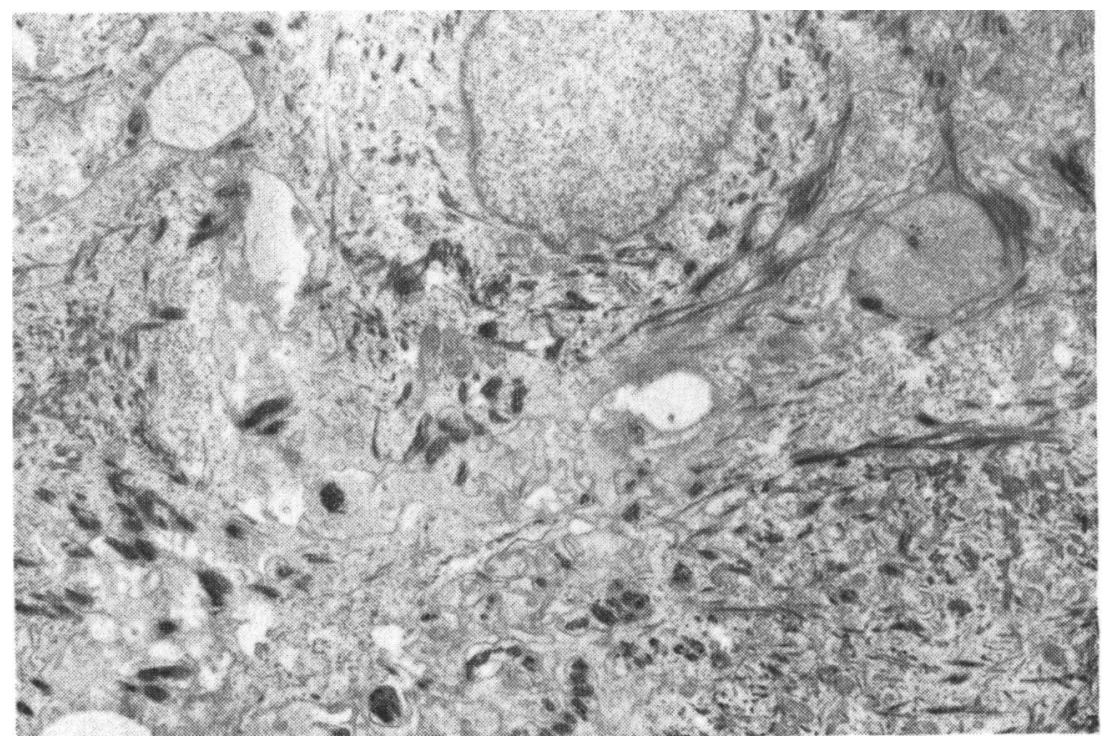

Figure 4. Polyhedral cells in keratitis. Note oedema and aggregations of filaments. $5,000 \times$. 


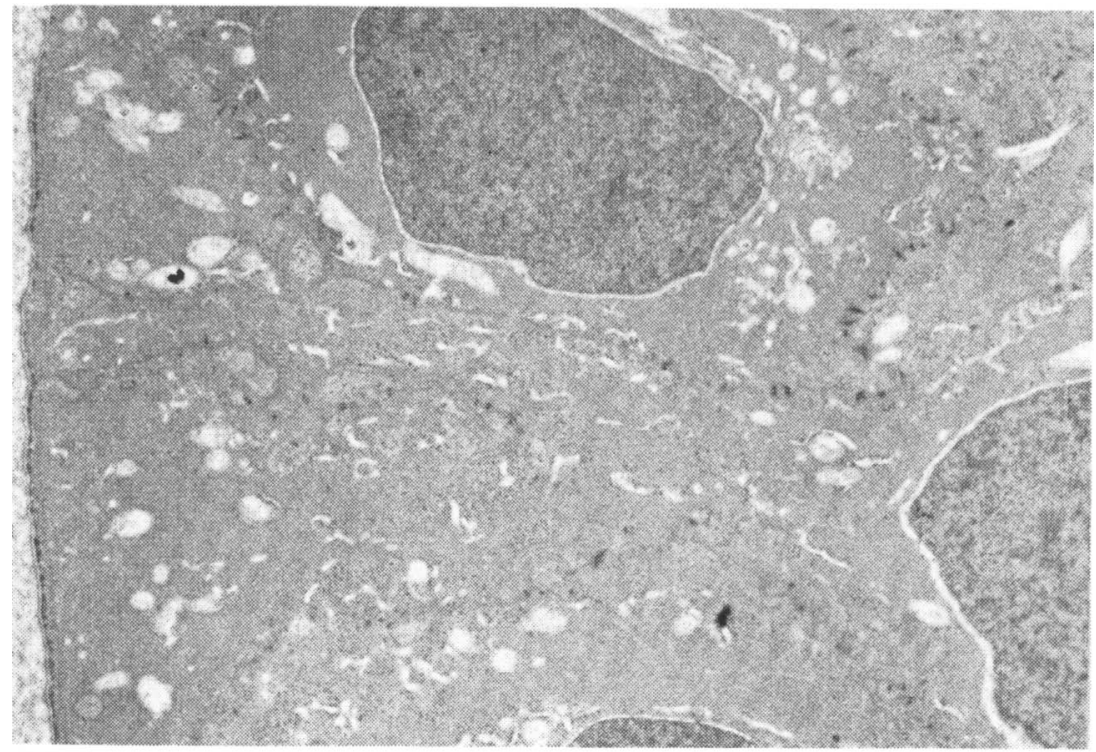

F ig u re 5. Normal columnar cells. Note basement membrane and hemidesmosomes. $5,000 \times$.

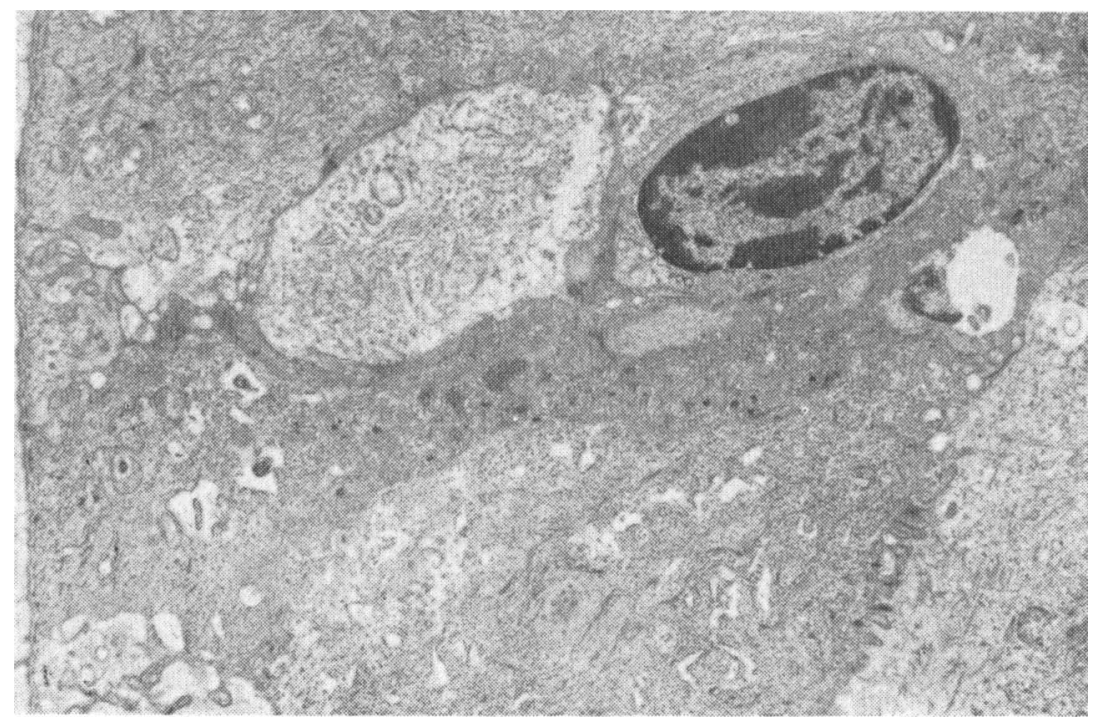

Figure 6. Columnar cells in keratitis. Note oedema, pycnotic nucleus and irregular filaments. $5,000 \times$. 


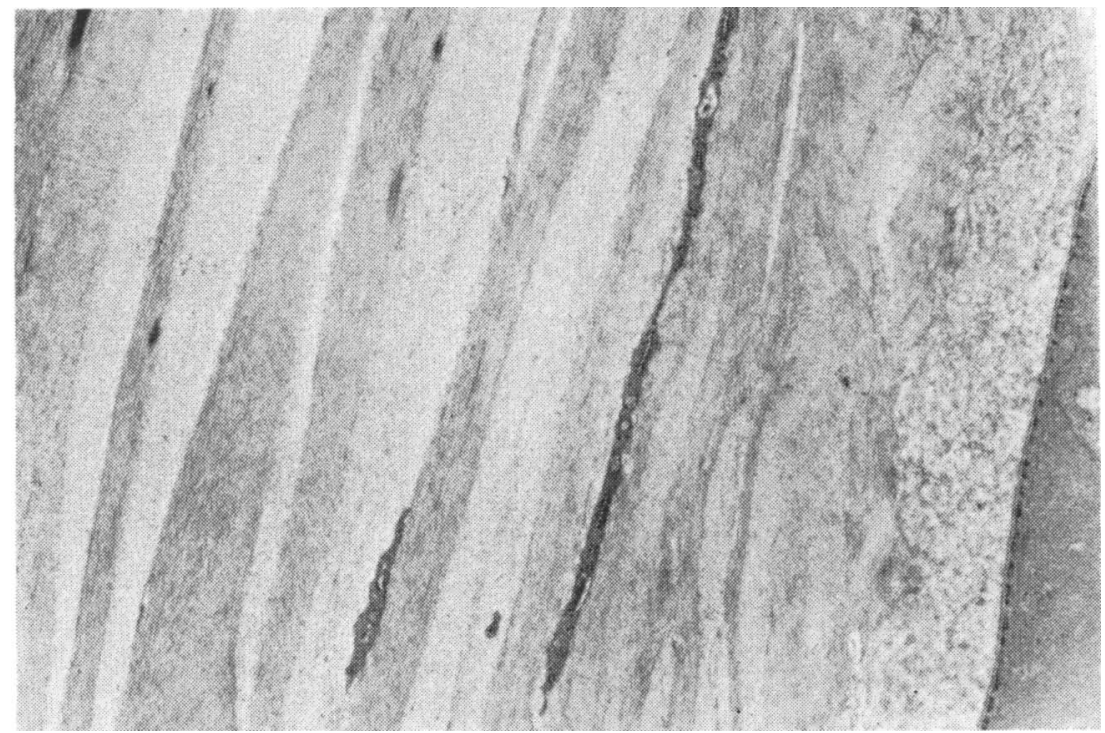

Figure 7. Part of normal substantia propria, anterior limiting lamina, and basement membrane. $5,000 \times$.

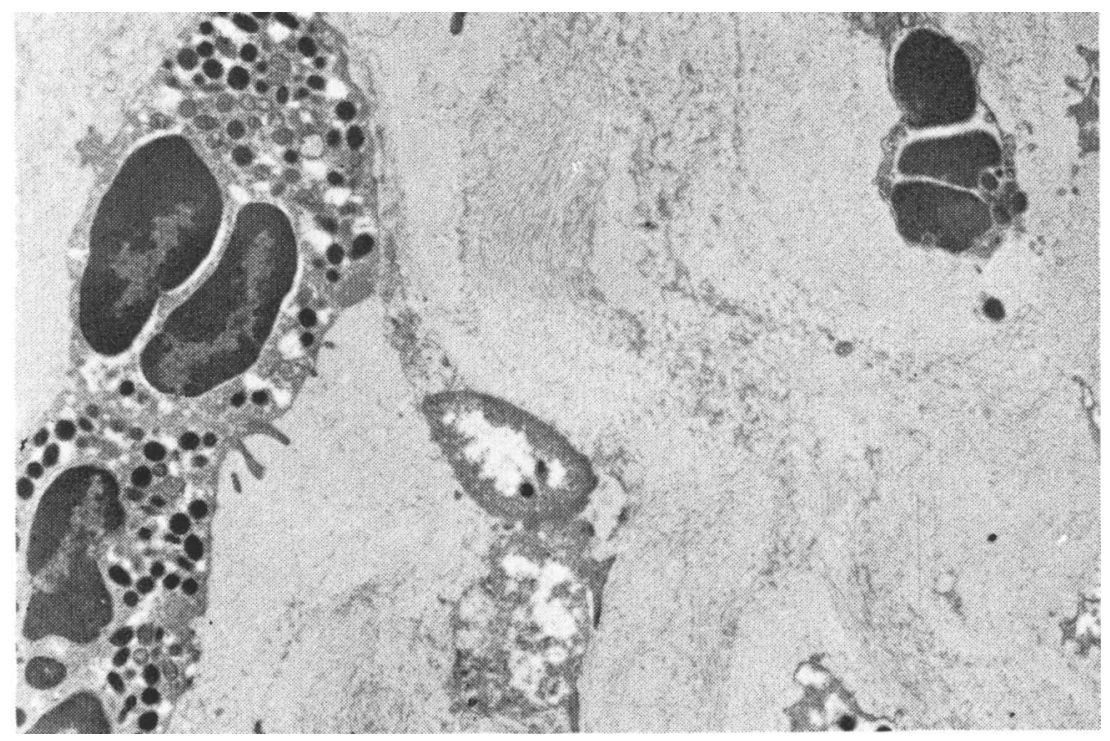

F i g u r e 8. Substantia propria in keratitis with vessel and neutrophil. Note swelling of collagen bundles. 5,000 $\times$. 